\title{
Relationship between Nucleus Swelling and Development Competence of Bovine Cloned Embryos Reconstructed by Enucleated Oocytes with Serum-starved or Serum-fed Fetal Somatic Cells
}

\author{
Mokhamad Fahrudin $^{1^{*}}$, Ni Wayan Kurniani Karja ${ }^{2}$ and Tatsuyuki Suzuki ${ }^{3}$
}

1. Faculty of Veterinary Medicine, Bogor Agricultural University, Bogor 16680, Indonesia.

2. Department of Reproduction and Obstetric, Faculty of Veterinary Medicine, Gadjah Mada University, Yogyakarta 55281, Indonesia.

3. Laboratory of Animal Reproduction and Biotechnology, The United Graduate School of Veterinary Sciences, Yamaguchi University, Yamaguchi 753-8515, Japan.

\begin{abstract}
This study was conducted to examine the occurrence of nuclear remodeling (nucleus swelling) and its effects on the subsequent in vitro development of bovine embryos reconstructed by serum-starved and serum-fed somatic cells. Results from this study demonstrated that all of the reconstructed embryos that received serum-starved and serum-fed somatic cells exhibited condensed-nuclei. More than $90 \%$ of the transferred nuclei exhibited nuclear envelope breakdown and premature chromatin condensation which clearly distinct from an intact nucleus. There was no significant difference on the degree of nucleus swelling in SS-NT embryos or SF-NT embryos, indicating that either serum-starved or confluent somatic cell lines could be reprogrammed by the recipient cytoplasm environments in similar pattern. Although the fusion rate was not significantly different among the groups, the proportion of SS-NT embryos which developed to the 2- to 4-cell stage $(89.7 \%)$ and to the 8 - to 16 -cell stage $(74.7 \%)$ was significantly higher than that of SF-NT embryos. Whereas, the proportion of reconstructed embryos that developed to the morula and blastocyst stages were not significantly different among the groups. Results of these studies demonstrate that reconstructed embryos, which received either serum-starved or serum-fed confluent somatic cells, showed similar developmental competence to the blastocyst stage.
\end{abstract}

Keywords: nuclear transplantation technique-somatic cells-nucleus swelling

\section{Introduction}

In nuclear transplantation technique, various somatic cells have been used as donor nuclei; either fetal fibroblast or adult somatic cell lines have been developed to term following transfer into enucleated oocytes (Wilmut et al., 1997; Wells et al., 1999; Cibelli et al., 1998; Kubota et al., 2000; Ogura et al., 2000). However, the exact mechanisms behind these successes are not fully determined. Therefore, further studies are needed to elucidate the mechanisms that

"Corresponding author: Mokhamad Fachrudin, Faculty of Veterinary Medicine, Bogor Agricultural University, Bogor 16680, Indonesia. E-mail address: udyne@yahoo.com. may regulate remodeling and reprogramming of the transferred somatic cell nuclei by enucleated oocytes cytoplasm. A quiescent state of donor cell nuclei that can be achieved by serum starvation has been thought to significantly improve the efficiency of nuclear transfer and development to term of the resultant reconstructed embryos (Wilmut et al., 1997). On the other hand, other reports demonstrated that quiescent status of donor cell may not necessary for nuclear transfer as actively dividing cell lines derived from fetus tissues have also supported the development to term of nuclear transplant embryos (Cibelli et al. , 1988). 
A series of morphological transitions are observed when the embryonic nuclei are fused into mature oocytes. These are characterized by a premature chromosome condensation (PCC) of the transferred nuclei that followed by the swelling of these nuclei upon activation of reconstructed embryos (Prather and First, 1990). Szollosi et al. (1988) has illustrated that transplanted nuclei can swell to a size similar to that of an endogenous pronuclei only when nuclei are fused to eggs in the period between metaphase II (MII) and telophase II. When nuclear transfer is delayed and occurs after telophase II, the nuclear membrane remains intact, interphase chromosomes did not decondense, and the donor nuclei did not develop to normal pronucleus structure. A more recent study showed that the occurrence of nuclear remodeling in the reconstructed embryos is cell cycle dependent (Collas et al., 1992a; Campbell et al., 1996). Although nuclear remodeling is of central importance in determining the fate of embryos reconstructed by nuclear transfer, little are known about the mechanisms that responsible for each event associated with this process.

Nuclear remodeling has been studied extensively in amphibians (Gurdon et al., 1976) and rabbits (Collas and Robl, 1991); however, little information is available on the occurrence of nuclear remodeling of somatic cell nuclei following transfer into enucleated oocytes. Therefore, this study was conducted to examine the occurrence of nuclear remodeling (nucleus swelling) and its effects on the subsequent in vitro development of bovine embryos reconstructed by serum-starved and serumfed somatic cells.

\section{Materials and Methods Oocytes collection}

Oocytes collection and in vitro maturation were carried out as previously described by Fahrudin et al. (2001). Briefly, ovaries were obtained from a local slaughterhouse, and transported to the laboratory in $0.9 \%$ sodium solution at 30 $35^{\circ} \mathrm{C}$. Cumulus-oocytes-complexes (COCs) were aspirated from 2-5 mm diameter follicles by $19 \mathrm{G}$ needle attached to $10 \mathrm{ml}$ syringe. COCs were washed once in modified phosphate buffered-saline supplemented with $50 \mu \mathrm{g} / \mathrm{mL}$ gentamicin sulfate (Sigma Chemical Co., USA) and three times in maturation medium which consisted of TCM 199 (Gibco, Grand Island, NY, USA) supplemented with $5 \%(\mathrm{v} / \mathrm{v})$ heat-inactivated fetal bovine serum (Gibco BRL), $50 \mu \mathrm{g} / \mathrm{ml}$ gentamicin sulfate, 0.02 $\mathrm{AU} / \mathrm{ml}$ follicle stimulating hormone $(\mathrm{FSH}$, Denka Pharmaceutical Co., Kawasaki, Japan), and $100 \mathrm{ng} / \mathrm{ml}$ somatotrophine (Sigma). The incubation of COCs in maturation medium was conducted at $38.5^{\circ} \mathrm{C}$ in a humidified atmosphere of $5 \%$ $\mathrm{CO}_{2}$ in air for $18-20 \mathrm{~h}$.

\section{Establishment of donor cell somatic cell \\ Unknown age fetus from} slaughterhouse was transported to the laboratory in $0.9 \%$ sodium solution at 30 $35^{\circ} \mathrm{C}$ within $3-5 \mathrm{~h}$ after slaughter. Fetus was then cut into small pieces $\left(0.5-1 \mathrm{~cm}^{2}\right)$, and subjected to enzymatical digestion in PBS solution that contained $0.25 \%$ tripsin (Difco, Detroit, USA) for $30 \mathrm{~min}$ at room temperature. The tissues were then briefly washed by adding DMEM (Gibco) medium supplemented with 5\% FBS and centrifuged at $3000 \mathrm{rpm}$ for $5 \mathrm{~min}$. The tissues were then cultured in $35 \mathrm{~mm}$ culture cell dish (Falcon, USA). After 10-14 ten days in culture, cell confluents were obtained. The cell confluents were recultured every 3 - 5 days to maintain adequate cell population. In this study, five to 12 passages of cell confluents were used as donor nuclei for nuclear transplantation. 


\section{Nuclear transfer (NT)}

At $20 \mathrm{hr}$ after the onset of IVM, cumulus cells were removed by pipetting vigorously after incubating the COCs in 300 IU hyaluronidase (Sigma) contained $\mathrm{Ca}$ and Mg-free PBS (Gibco) for $2 \mathrm{~min}$. Only oocytes exhibiting polar body and evenly granulated cytoplasm were subjected for further manipulation. Selected oocytes were washed in manipulation medium [PBS (with Calcium and Magnesium, Gibco) containing $5 \mu \mathrm{g} / \mathrm{ml}$ cytochalasin B and $0.3 \%$ BSA (Sigma)] supplemented with 10 $\mu \mathrm{g} / \mathrm{ml}$ vital dye Hoechst 33342 (Calbiochem, San Diego, CA, USA) and held in this medium for $20 \mathrm{~min}$ before being enucleated. Enucleation of the metaphase plate chromosome was accomplished by squeezing out the first polar body and a small amount of the cytoplasm adjacent to the first polar body after cutting the zona pellucida by a sharp glass needle (Figure 1.a,b). The squeezed ooplasm were then evaluated under a fluorescence microscope to confirm successful enucleation (Figure 1.c). Only enucleated-oocytes were selected as recipient oocytes.

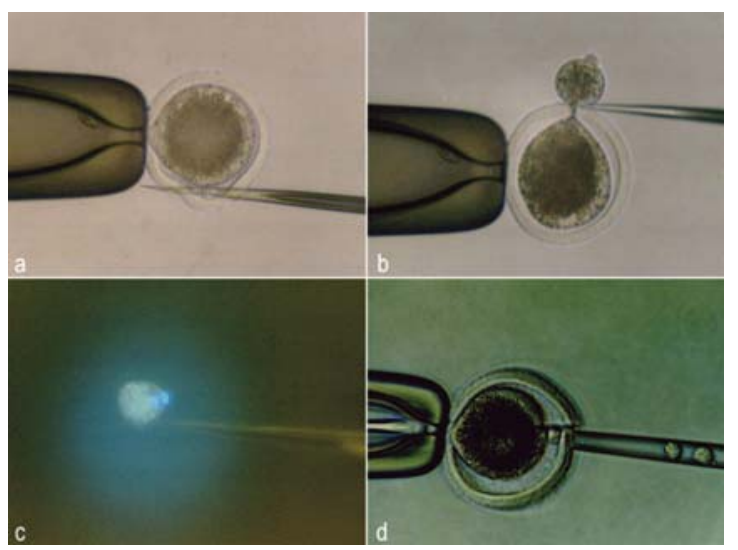

Figure 1. Preparation of recipient oocytes by squeezeout method and transfer of donor karyoplast. Incision of zona pellucida with a sharp glass needle (a). Cutting of cytoplasm with a glass needle (b). Morphology of polar body and metaphase under epifluorescence microscopy (c). Insertion of donor karyoplast into perivitelline space of recipient cytoplast $(\mathrm{d})$.
Nuclear transplantation was achieved at 22-24 $\mathrm{h}$ post maturation in vitro, by inserting the donor karyoplast into perivitelline space of the recipient cytoplast through a slit that was made in the zona pellucida during enucleation (Figure 1.d). A single cell suspension of the donor cells was prepared by standard typsinization by a mixture of $0.25 \%$ trypsin: $0.02 \%$ EDTA (1:4) in tris solutions. The cell pellet was re-suspended in DMEM supplemented with $5 \%$ FCS. In order to facilitate contact between donor cell and recipient cytoplast, donor cells were placed in manipulation medium containing $40 \mu \mathrm{g} / \mathrm{ml}$ of phytohemagglutinin (Sigma) before being inserted into the recipient cytoplast. Following insertion of the donor nuclei, the reconstructed embryos were equilibrated through mixtures of Zimmerman fusion and CR1aa media (1:2; 2:1, respectively), and then deposited into a fusion chamber with two stainless steel electrodes $1 \mathrm{~mm}$ apart overlaid with Zimmerman fusion medium. The reconstructed embryos were manually aligned with a fire polished glass needle so that the contact surface between the cytoplast and the donor cell was parallel to the electrodes. Cell fusion was initiated by a single DC pulse of $1 \mathrm{kV} / \mathrm{cm}$ for $50 \mu \mathrm{sec}$, delivered by a BTX Electro Cell Manipulator 2001 (BTX, San Diego, CA).

Fusion of the reconstructed embryos was determined under a light microscope. Following fusion, the reconstructed embryos were washed in CR1aa medium and then were activated parthenogenetically by culturing the embryos in $10 \mathrm{mg} / \mathrm{ml}$ calcium ionophore (Sigma) for $5 \mathrm{~min}$ and followed by culturing in the CR1aa medium containing $10 \mu \mathrm{g} / \mathrm{ml}$ of cycloheximide (Wako, Japan) for $5 \mathrm{~h}$. After activation, the couplets were briefly washed in CR1aa culture medium and then five to ten reconstructed embryos were cultured in a 
$100 \mu \mathrm{l}$ drops of CR1aa culture medium for $7-8$ days at $38.5^{\circ} \mathrm{C}$ under $5 \% \mathrm{CO}_{2}$ in air.

\section{Experimental design}

Assessment of the morphological transition of transplanted nuclei

In order to explore the effect of morphological events on transplanted nuclei on the subsequent development in vitro of reconstructed embryos, immediately after fusion, and $5 \mathrm{~h}$ after the onset of fusion, some of the reconstructed embryos received serum-starved or serum-fed somatic cells which were incubated in Hoechst H33342 contined CR1aa medium for $10 \mathrm{~min}$ and then were observed under a fluorescent microscope for a few seconds. The couplets were then briefly washed in CR1aa medium and re-cultured to assess further developmental competence. Some of the fusion couplets were fixed in ethanol:acetic acid for (3:1) for $24 \mathrm{~h}$ and stained with $1 \%$ $(\mathrm{w} / \mathrm{v})$ orcein dissolved in warmed acetic acid to clarify the morphological transition of the nucleus. In this experiment, following assessment of nucleus morphology, the subsequent reconstructed embryos were divided into two groups, i.e, the reconstructed embryos that exhibited nucleus swelling and those that not exhibiting nucleus swelling.

The in vitro NT embryos received serumstarved and serum-fed donor nuclei

In order to examine developmental competence of reconstructed embryos receiving serum-starved (SS-NT group) or serum-fed somatic cells as donor nuclei (SFNT group), two kinds of donor nuclei were used in this study. Serum-starved donor nuclei were prepared from confluent cells that were cultured in DMEM supplemented with $0.5 \%$ FBS for $4-5$ days before used as donor nuclei. Serum-fed donor nuclei were derived from somatic cell confluents that were continuously cultured in DMEM supplemented with 5\% FBS.

\section{Statistical analysis}

Experiments were conducted at least six replicates. All data were analyzed statistically by chi-squared analysis or, when some expected values less than 0.05 were obtained, Fisher's exact probability test was used. Differences with a probability value $(\mathrm{P})$ of less than 0.05 were considered significant.

\section{Results}

\section{The morphological transition of} transplanted nuclei

Morphological transition of transferred nuclei in NT embryos was summarized in Table 1 and Table 2.

Table 1. The morphological transition of somatic cell nuclei at $5 \mathrm{~h}$ after fusion with enucleated MII oocytes observed under epifluorescence microscopy.

\begin{tabular}{|c|c|c|c|c|c|c|c|}
\hline \multirow[t]{2}{*}{$\begin{array}{c}\text { NT } \\
\text { embryos }\end{array}$} & \multirow{2}{*}{$\begin{array}{c}\text { No. of } \\
\text { embryos } \\
\text { examined }\end{array}$} & \multicolumn{3}{|c|}{$\begin{array}{l}\text { Exhibited Nucleus } \\
\text { Swelling(\%) }\end{array}$} & \multicolumn{3}{|c|}{$\begin{array}{l}\text { Not Exhibited Nucleus } \\
\text { Swelling(\%) }\end{array}$} \\
\hline & & $\begin{array}{c}\text { No. of } \\
\text { coup- } \\
\text { lets }\end{array}$ & $\begin{array}{l}\text { Cleav- } \\
\text { age }\end{array}$ & $\begin{array}{l}\text { Blast- } \\
\text { ocyst }\end{array}$ & $\begin{array}{c}\text { No. of } \\
\text { coup- } \\
\text { lets }\end{array}$ & $\begin{array}{l}\text { Cleav- } \\
\text { age }\end{array}$ & $\begin{array}{l}\text { Blast- } \\
\text { ocyst }\end{array}$ \\
\hline SS-NT* & 57 & $\begin{array}{c}42 \\
(73.7)\end{array}$ & $\begin{array}{c}37 \\
(88.1)\end{array}$ & $\begin{array}{c}18 \\
(42.9)\end{array}$ & $\begin{array}{c}13 \\
(22.8)\end{array}$ & $\begin{array}{c}6 \\
(46.1)\end{array}$ & $\begin{array}{c}1 \\
(7.7)\end{array}$ \\
\hline SF-NT & 72 & $\begin{array}{c}53 \\
(73.6)\end{array}$ & $\begin{array}{c}44 \\
(83.0)\end{array}$ & $\begin{array}{c}22 \\
(41.5)\end{array}$ & $\begin{array}{c}19 \\
(26.3)\end{array}$ & $\begin{array}{c}11 \\
(57.9)\end{array}$ & $\begin{array}{c}3 \\
(15.8)\end{array}$ \\
\hline
\end{tabular}

*) Two NT embryos revealed fragmented nuclei at $5 \mathrm{~h}$ after fusion.

Table 2. The morphological transition of somatic cell nuclei at 1 and $5 \mathrm{hr}$ after fusion with enucleated MII oocytes observed after stained with orcein dye.

\begin{tabular}{cccc}
\hline NT Embryos & $\begin{array}{c}\text { No. of NT } \\
\text { embryos } \\
\text { examined }\end{array}$ & $\begin{array}{c}\text { NEBD and } \\
\text { PCC (\%) }\end{array}$ & $\begin{array}{c}\text { PN-like } \\
\text { structure (\%) }\end{array}$ \\
\hline SS-NT & 70 & $34 / 36(94.4)$ & $29 / 34(85.2)$ \\
\hline SF-NT & 69 & $32 / 35(91.4)$ & $30 / 34(88.2)$ \\
\hline
\end{tabular}

In the reconstructed embryos that received serum-starved and serum-fed 
somatic cells, all of the reconstructed embryos exhibited condensed-nuclei (which were at interphase stage), and the diameter of the nuclei were comparable to the size of the donor nuclei after fusing with recipient cytoplasm (Figure 2.a,b). The morphological observation by orcein dye showed that 94.4 to $91.4 \%$ of the transferred nuclei exhibited nuclear envelope breakdown and premature chromatin condensation which clearly distinct from an intact nucleus (Figure 3.a,b).

Five hours after the onset of fusion, $73.7 \%$ of the SS-NT embryos exhibited nuclear swelling which may have been associated with the formation of pronuclearlike structure (Figure 2.c, 3.c), $88.1 \%$ and $42.9 \%$ of these embryos developed to the 2cell stage, and blastocyst stage, respectively. The development of SF-NT embryos were $73.6 \%, 83.0 \%$ and $41.5 \%$, for embryos that revealed nuclear swelling, cleaved and developed to the blastocyst stage, respectively.

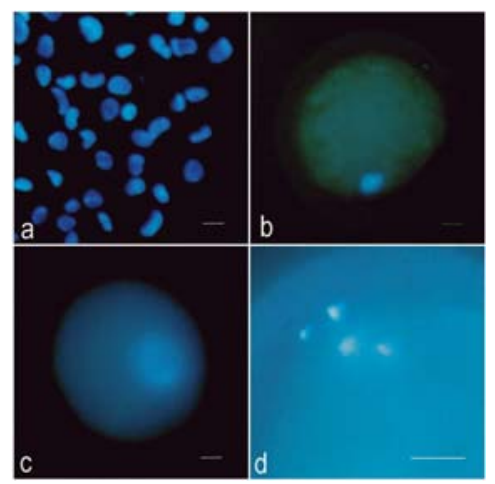

Figure 2. Morphology of nuclear transformation in the embryos reconstructed by somatic nuclear transfer after staining with Hoechst 33342, observed under epifluorescence microscopy. The morphology of donor nuclei (a). Morphology of transferred nuclei at $1 \mathrm{~h}$ after fusion (b) and $5 \mathrm{~h}$ after the onset of fusion (c). Abnormal karyomorphism of the transferred nuclei $5 \mathrm{hr}$ after fusion (d). (Bar $=15 \mu \mathrm{m})$.

Developmental competence of NT embryos that did not exhibit nuclear swelling following fusion in the SS-NT and SF-NT embryos were $46.1 \%$ and $57.9 \%$ for cleavage rate, respectively, while the blastocyst rate were $7.7 \%$ and $15.8 \%$, respectively.

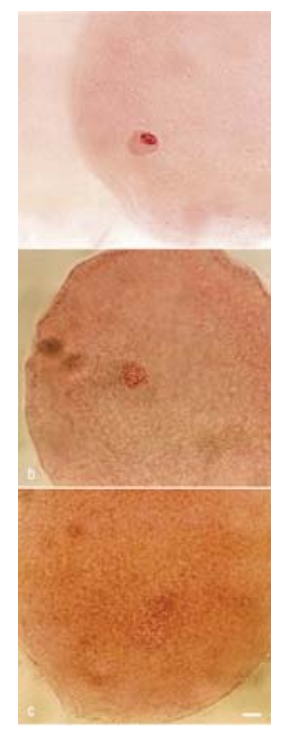

Figure 3. Morphology of nuclear transformation in the embryos reconstructed by somatic nuclear transfer after staining with aceto-orcein. The morphology of trans-ferred nuclei immediately after fusion (a,b) and $5 \mathrm{~h}$ after the onset of fusion (c). (Magnification 200x, Bar $=15 \mu \mathrm{m}$ ).

Developmental competence of NT embryos received serum-starved or serum-fed donor nuclei

Developmental competence of NT embryos receiving serum-starved or serumfed donor nuclei was shown in Table 3. The fusion rate was not significantly different $(68.1 \%$ vs $72.6 \%)$ between groups of NT embryos. The proportion of SS-NT embryos developed to the 2- to 4-cell stage $(89.7 \%)$ and to the 8 - to 16 -cell stage $(74.7 \%)$ was significantly higher $(\mathrm{P}<0.05)$ than those of SF-NT embryos $(73.1 \%$ and $61.3 \%$, respec-tively). However, the proportion of NT embryos that developed to the morula and blastocyst stages were not significantly different among the groups $(51.4 \%$ and $39.3 \%$ vs $45.1 \%$ and $37.6 \%$, for SS-NT embryos vs SF- NT embryos, respectively). 
Table 3. The development in vitro NT embryos received serum-starved and serum-fed somatic cells

\begin{tabular}{|c|c|c|c|c|c|c|}
\hline \multirow[t]{2}{*}{$\begin{array}{c}\text { NT } \\
\text { Embryos }\end{array}$} & \multirow[t]{2}{*}{$\begin{array}{l}\text { No. of } \\
\text { embryos }\end{array}$} & \multirow[t]{2}{*}{$\begin{array}{l}\text { No. of } \\
\text { Fused }\end{array}$} & \multicolumn{4}{|c|}{$\begin{array}{l}\text { No. of NT Embryos } \\
\text { developed to }(\%)^{*}\end{array}$} \\
\hline & & & $\begin{array}{c}\text { 2- to } 4 \\
\text { cell }\end{array}$ & $\begin{array}{c}\text { 8- to } 16 \\
\text { cell }\end{array}$ & $\begin{array}{l}\text { Mor- } \\
\text { ula }\end{array}$ & $\begin{array}{l}\text { Blast- } \\
\text { ocyst }\end{array}$ \\
\hline SS - NT & 157 & $\begin{array}{c}107 \\
(68.1)\end{array}$ & $\begin{array}{c}96 \\
(89.7)^{\mathrm{a}}\end{array}$ & $\begin{array}{c}80 \\
(74.8)^{\mathrm{a}}\end{array}$ & $\begin{array}{c}55 \\
(51.4)\end{array}$ & $\begin{array}{c}42 \\
(39.3)\end{array}$ \\
\hline$S F-N T$ & 128 & $\begin{array}{c}93 \\
(72.6)\end{array}$ & $\begin{array}{c}68 \\
(73.1)^{b}\end{array}$ & $\begin{array}{c}57 \\
(61.3)^{\mathrm{b}}\end{array}$ & $\begin{array}{c}42 \\
(45.1)\end{array}$ & $\begin{array}{c}35 \\
(37.6)\end{array}$ \\
\hline
\end{tabular}

* Values was calculated based on number of fusion. $\mathrm{a}, \mathrm{b}$ Superscript within the same column was significantly different at $\mathrm{P}<0.05$

\section{Discussion}

It has been suggested that a high level of maturation promoting factor (MPF) during oocyte maturation is necessary for the occurrence of nuclear remodeling. In the early study of nuclear transplantation by transferring embryonic cells (blastomeres), morphological transition on transferred nuclei such as condensation of chromatin followed by swelling of the nucleus had been reported in mice (Cheong et al., 1993, 1994), rabbits (Collas and Robl, 1991), and cattle (Ushijima and Eto, 1994). In this study, we conducted the manipu-lation of the oocytes at 22-24 $\mathrm{h}$ after the onset of in vitro maturation and, as was expected, a greater proportion of the transplanted nuclei that fused into enucleated-MII oocytes exhibited premature condensation and nuclear swelling following cultured for $5 \mathrm{~h}$ from the onset of fusion. In the study of bovine nuclear transfer by transferring embryonic cells into enucleated matured oocytes, it has been reported that the transferred nucleus tends to swell after transplant into enucleated oocytes (Ushijima and Eto, 1994; Takano et al., 1996). The results of our study are in agreement with the previous studies showing that the majority of transferred nuclei showed chromosome condensation following fusion and the nuclear swelling associated with the formation of pronucleus like structure occurred at $5 \mathrm{~h}$ after the onset of fusion. Observation on the labeled nuclei with Hoechst 33342 under fluorescent microscopy showed that the diameter of transferred nuclei swelled 3- to 5-fold compared to the original size $(10-15 \mu \mathrm{m})$, and there was no significant difference on the degree of nucleus swelling in SS-NT embryos or SF-NT embryos. These results reflected that either serum-starved or confluent somatic cell lines could be reprogrammed by the recipient cytoplasm environments in similar pattern. The high proportion of reconstructed embryos developed to the blastocyst stage also demonstrated that the occurrence of nucleus swelling in the reconstructed embryos accelerate the developmental competence of reconstructed embryos to the blastocyst stage.

The development of reconstructed embryos that did not exhibit a modified nucleus was observed during culture in vitro. These results might caused by asynchrony of maturation of oocytes, in which the maturation status of cytoplasm oocytes progressed more than expected and, as a result, the cell cycle phase of the cytoplasm was not at M-phase but rather in S-phase. In this case, the "universal recipient" phenomenon (Campbell et al., 1993, 1996) may account for this result.

Nuclear transfer into enucleated MII oocytes in cattle (Ushijima and Eto, 1994), mice (Tarkowski and Balakier, 1980), and rabbits (Collas et al., 1992b) shows that chromatin is occasionally scattered, and that the nuclei display abnormal karyomorphism. The results of our study demonstrated that only a small number of SF-NT embryos that received confluent somatic cells exhibited abnormal karyomorphism in the first cycle, even though 2/57 of the SS-NT embryos exhibited fragmented nuclei after culture for $5 \mathrm{~h}$ (Fig 2.d) and 1/34 of the SF-NT embryos revealed two separated metaphase nuclei. 
In this study, only a small number of nuclear transplants revealed abnormal karyomorphism, possibly caused by the cycle of donor nuclei with a presumptive $G_{1} /$ $\mathrm{G}_{0}$ (Wilmut et al., 1997; Cibelli et al., 1998). This results in agreement with a previous study (Collas et al., 1992b) demonstrating that the transplantation of $G_{1}$ into enucleated MII oocytes improves the proportion of embryos with normal karyomorphism and their subsequent development into the blastocyst stage.

It has been reported that by putting the donor nuclei at the border $G_{0}$ cell cycle by serum starvation may significantly increase the developmental potential of reconstructed embryos when it was transferred into the MII cytoplasm environment (Wilmut et al., 1997). In this study, a high proportion of the reconstructed embryos that received serumstarved (presumptive to be quiescent) nuclei developed to 2- to 4-cell stages and 8- to 16cell stages. However, the subsequent development in vitro of SS-NT embryos to the morulae and blastocyst stages were not significantly different compared to SF-NT embryos. Unfortunately, the analysis of the morphological transition could not clarify this phenomenon. Otherwise, the rate of development to the blastocyst stage in SSNT and SF-NT embryos demonstrated that both cell lines have similar competency being reprogrammed by recipient cytoplasm. Recently, it has been reported that serum deprivation causes apoptosis in cultured cells (Kues et al., 2000). If apoptotic occurs in the transferred nuclei, it should be considered as one of the factor that may be responsible for reduction of development to the blastocyst stage. Further studies should be conducted to elucidate this phenomenon in order to improve the efficiency of nuclear transplantation.

In conclusion, an increased proportion of bovine reconstructed embryos that receiving serum-starved or serum-fed confluent somatic cells revealed nuclear swelling to a similar extent when reconstructed with MII-enucleated oocytes. Results of these studies demonstrate that reconstructed embryos, which received either serum-starved or serum-fed confluent somatic cells, showed similar developmental competence to the blastocyst stage.

\section{References}

Campbell, K.H.S., Loi, P., Otaegui, P. J., and Wilmut, I., 1996. Cell cycle coordination in embryo cloning by nuclear transfer. Rev. Reprod. I, 4046.

Campbell, K.H.S., Ritchie, W.A., and Wilmut, I., 1993. Nuclearcytoplasmic interactions during the first cell cycle of nuclear transfer reconstructed embryos: implications for deoxyribonucleic acid replication and development. Biol. Reprod. 49, 933-942.

Cheong, H.T., Takahashi, Y., and Kanagawa, H., 1993. Birth of mice after trans-plantation of early cellcycle stage embryonic nuclei into enucleated oocytes. Biol. Reprod. 48, 958-963.

Cheong, H.T., Takahashi, Y., and Kanagawa, H., 1994. Relationship between nuclear remodeling and subsequent development of mouse embryonic nuclei transferred into enucleated oocytes. Mol. Reprod. Dev. 37, 138-145.

Cibelli, J.B., Stice, S.L., Golueke, P.J., Kane, J.J., Jerry, J., Blackwell, C., Ponce De Leon, A., and Robl, J.M., 1998. Cloned transgenic calves produced from nonquiescent fetal fibroblasts. Science, 280, 1256-1258.

Collas, P., and Robl, J.M., 1991. Relationship between nuclear remodeling and development in nuclear transplant rabbit embryos. Biol. Reprod., 45, 455-465. 
Collas, P., Balise, J.J., and Robl, J.M. 1992a. Influence of cell cycle stage of the donor nucleus on development of nuclear transplant rabbit embryos. Biol. Reprod., 46, 492-500.

Collas, P., Pinto-Correia, C., Pone De Leon, F.A., and Robl, J.M., 1992. Effect of donor cell cycle stage on chromatin and spindle morphology in nuclear transplant rabbit embryos. Biol. Reprod., 46, 501-511.

Gurdon, J.B., Partington, G.A., and De Robertis, E.M., 1976. Injected nuclei in frog oocytes: RNA synthesis and protein exchange. J. Embryol. Exp. Morph., 36, 541-553.

Fahrudin, M., Otoi, T., Suzuki, T., 2001. Developmental competence of bovine embryos reconstructed by the transfer of somatic cells derived from frozen tissues. J. Vet. Med. Sci., 63, 1151-1154.

Kubota, C., Yamakuchi, H., Todoroki, J., Mizoshita, K., Tabara, N., Barber, M., and Yang, X., 2000. Six cloned calves produced from adult fibroblast cells after long-term culture. Proc. Natl. Acad. Sci. USA., 97, 990-995.

Kues, W.A., Anger, M., Carnwath, J.W., Paul, D., Motlik, J., and Nieman, H., 2000. Cell cycle synchronization of porcine fetal fibroblasts: effects of serum deprivation and reversible cell cycle inhibitors. Biol. Reprod., 62, 412-419.

Ogura A., Inoue, K., Ogonuki, N., Noguchi, A., Takano, K., Nagano, R., Suzuki, sO., Lee, J., Ishino, F., and Matsuda, J., 2000. Production of male cloned mice from fresh, cultured, and cryopreserved immature sertoli cells. Biol. Reprod., 62, 1579-1584.

Prather, R.S., and First, N.L., 1990. Cloning embryos by nuclear transfer. J. Reprod. Fertil. (Suppl.), 41, 125-134.
Rosenkrans, Jr.C.F., Zeng, G.Q., Mcnamara, G.T., Schoff, P.K., and First, N.L., 1993. Development of bovine embryos in vitro as affected by energy substrates. Biol. Reprod. 49, 459-462.

Szollosi, D., Czolowska, R., Szollosi, M.S., and Tarkowski, A.K., 1988. Remodelling of mouse thymocyte nuclei depends on the time of their transfer into activated, homologous oocytes. J. Cell Sci., 91, 19-34.

Takano, H., Koyama, K., Kozai, C., Shimizu, S., Kato, Y., and Tsunoda, Y., 1996. Effects of cell cycle stage of donor nuclei on the development of bovine nuclear transferred embryos. J. Reprod. Dev., 42, 61-65.

Tarkowski, A.K. and Balakier, H., 1980. Nucleo-cytoplasmic interaction in cell hybrids between mouse oocytes, blastomere and somatic cells. J. Embryol. Exp. Morph., 55, 319-330.

Ushijima, H. and Eto, T., 1994. Bovine nuclear transplantation using a parthe-nogenetically activated oocytes as the recipient oocytes. $J$. Reprod. Dev., 40, 117-124.

Wells, D.N., Misica, P.M., Day, A.M., and Tervit, H.R., 1997. Production of cloned lambs from established embryonic cell line: a comparison between in vivo-and in vitromatured cytoplast. Biol. Reprod., 57, 385-393.

Wells, D.N., Misica, P.M., and Tervit, H.R., 1999. Production of cloned calves following nuclear transfer with cultured adult mural granulose cells. Biol. Reprod., 60, 996-1005.

Wilmut, I., Schnieke, A.E., McWhir, J., Kind, A.J., and Campbell, K.H.S., 1997. Viable offspring derived from fetal and adult mammalian cells. Nature, 385, 810-813. 